\title{
Studies on the Quality of Fish Cutlet Prepared from Rohu (Labeo rohita) during Refrigerated Storage
}

\author{
S. Sowmya Praneetha ${ }^{1}$, K. Dhanapal ${ }^{1 *}$, G.V.S. Reddy ${ }^{2}$, \\ A. Balasubramanian ${ }^{3}$ and G. Praveen Kumar ${ }^{1}$ \\ ${ }^{1}$ College of Fishery Science, S.V. Veterinary University, Muthukur 524 344, \\ Nellore District, Andhra Pradesh, India \\ ${ }^{2}$ Fisheries Research Station, Palair, Khamman District, Telangana State, India \\ ${ }^{3}$ Fisheries Research Station, Undi, West Godavari District, Andhra Pradesh, India \\ *Corresponding author
}

\section{A B S T R A C T}

A study on quality assessment of refrigerated stored fish cutlet prepared from rohu Labeo rohita and its proximate composition, biochemical, microbiological and organoleptical changes was carried out. The yield rate of minced meat from the whole fish was $39.31 \%$. The moisture and protein content of fish cutlet during refrigerated storage decreased

\section{Keywords}

Rohu, Fish cutlet, Organoleptic, Shelf life, Storage.

Article Info

Accepted:

23 October 2017

Available Online:

10 December 2017 significantly from $57.03 \%$ to $52.13 \%$ and $21.74 \%$ to $18.86 \%(\mathrm{P}<0.01)$ respectively while fat and ash content increased significantly from $7.61 \%$ to $16.76 \%$ and $3.41 \%$ to $4.49 \%$ $(\mathrm{P}<0.01)$ respectively. The $\mathrm{pH}$ of fish cutlet increased significantly $(\mathrm{P}<0.01)$ from 6.41 to 6.78. Peroxide value of fish cutlet during the initial storage period increased from 8.86 to $21.0 \mathrm{meq} \mathrm{O}_{2} / \mathrm{kg}$ of fat, till the end of $5^{\text {th }}$ day of storage and subsequently decreased to 11.6 meq $\mathrm{O}_{2} / \mathrm{kg}$ of fat at the end of storage period. The FFA content and TBA of fish cutlet was gradually increased from 0.0022 to $0.0061 \%$ of oleic acid and 0.129 to $0.860 \mathrm{mg} \mathrm{MA} / \mathrm{kg}$ of sample respectively $(\mathrm{P}<0.01)$. TVBN content also steadily increased significantly $(\mathrm{P}<0.01)$ from an initial value of 2.81 to $4.61 \mathrm{mg} / 100 \mathrm{~g}$ sample during refrigerated storage. TPC of bacteria was steadily increased $(\mathrm{P}<0.01)$ from the initial count of $4.30 \mathrm{x}$ to $7.56 \mathrm{x}$ $10^{4} \mathrm{cfu} / \mathrm{g}$ of sample. Similarly the psychrophilic count was also increased from $2.12 \times 10^{2}$ to $4.48 \times 10^{4} \mathrm{cfu} / \mathrm{g}$ of sample. The overall mean acceptability scores for the fish cutlet reduced significantly $(\mathrm{P}<0.01)$ with increase of storage period. The ideal shelf life for storing the fish cutlet in refrigerated condition was found as 12 days.

\section{Introduction}

In modern world, people hardly find time to cook which encourages a demand for "ready to cook" or "ready to serve" foods. In this category, fishery products also play an important role in the part of meat eaters. Unlike olden days, nowadays, the fishery products are hygienically prepared and attractively packed as convenience foods to match the changing needs of urban population. Ready to cook or serve fishery products receive good consumer preference not only in International but also in Indian market. If it is prepared from by catch and discards, it further augment the economical growth of the producers and the nation as well. The present fishing practices devastated 
the most of the fishery resources which lead to depletion of wild resources through landing of huge quantity of by catch and discards. In this context, the focus is on aquaculture production to sustain the fishery production. Many of the freshwater and brackish water bodies are now utilized for production of fishes. Most of the productions are utilized domestically and export of fresh water fish is negligible. Excess production of fresh water fishes often fetches poor market channel for selling their harvest, results in less price and in the market and hence profit loss to the aqua farmers. Further, in India, farmers or buyers do not venture for further processing and preparing value added products from the fresh water fishes. Indian Major Carps like Catla, Rohu, Mrigal, Common carp, Silver carpand Grass carp, are widely cultured by the Indian fish farmers as they are easy to culture and yield good production which contributes the market share of more than $90 \%$. Further, in many part of the country people do not prefer carp fishes due to presence of intramuscular bones. In this juncture, it is essential to encourage the utilization of carp meat through development of various convenience products which is acceptable to the consumers (Gopakumar, 1997).

Many researchers involved in value addition to the carps meat and developed as surimi (Shankar and Ramachandra, 2005), fish patties, fingers (Sehgal and Sehgal, 2002), etc. Battered and breaded or coated systems have the benefits of versatility and familiarity because they enhance the flavor and texture of processed food products (Biswas et al., 2004). These prepared products can be stored in different temperature as refrigerated and cold storage. Freezing and frozen storage of fish cutlet, fish finger and fish burger are commonly used because of the consistency, reliable quality, ease of transportation and the fact that they are very close to fresh equivalents (Tokur et al., 2004 and Sharma et $a l ., 2000)$. The main parameters which affect the shelf life of the stored products are the production form, features of packing material, storage temperature, packing process and machines that are used (Baygar et al., 2008). In these circumstances, the present study on quality evaluation of fish cutlet prepared from rohu fish stored in refrigerated condition receives significance.

\section{Materials and Methods}

Rohu (Labeo rohita) with the mean length of $36.75 \pm 2.98 \mathrm{~cm}$ and weight of $884.40 \pm$ 114.77 grams were collected from nearby commercial fish ponds. After bringing the fish in iced condition to the laboratory, they were washed and dressed to separate the meat using rotary type deboner (Safe World, Malaysia). The deboned fish meat was later minced to uniform sized particles using a mincer (Sirman, Italy). The recipe for preparation of fish cutlet was standardized by preparing different recipe with various tastes and analyzed organoleptically to find out a right formula of recipe for the preparation of fish cutlet. Based on the highest average organoleptic scores for all attributes, the best recipe was selected with the ingredients of 45 $\%$ Minced meat, 15\% Shrimp meat, $10 \%$ Potatoes, $3.3 \%$ wheat flour, $1.5 \%$ salt, $1 \%$ sugar, $0.2 \%$ Mono Sodium Glutamate, $1 \%$ Chili powder, $5 \%$ onion, $0.1 \%$ Baking powder, $8 \%$ Egg white, $9 \%$ Bread crumps, $0.2 \%$ Ginger, $1.5 \%$ Garam masala and $0.2 \%$ Coriander leaves.

Minced fish meat was cooked under 0.5 $\mathrm{kg} / \mathrm{cm}^{2}$ steam pressure for 20 minutes and all the ingredients were mixed along with blanched shrimps. After mixing, $25 \mathrm{~g}$ weight of paste was taken and made into ball and flattened into $1 \mathrm{~cm}$ thickness of round shape. Flattened ball was later battered by dipping it in egg and rolling in the bread crumbs powder. After battering, they were flash fried at $180^{\circ} \mathrm{C}$ for 30 seconds. The products were later cooled, packed in HDPE pouches, 
sealed, labeled and stored at $4{ }^{\circ} \mathrm{C} \pm 11^{\circ} \mathrm{C}$ for quality evaluation. Cutlets were evaluated for microbial, physicochemical and sensory characteristics on the day of preparation and during subsequent storage period.

Samples were drawn randomly in duplicate on every alternate day up to 15 days of refrigerated storage to analyze proximate, sensory, microbiological and biochemical parameters. Microbial analysis was first carried out aseptically followed by the analysis of proximate, biochemical and sensory were conducted by bringing the sample from the refrigerated temperature to room temperature. All the parameters were analysed in triplicate starting from the day of preparation of the product i.e., $0^{\text {th }}$ day of preparation. Mean sensory numerical scores were obtained based on the assessment carried out by seven panelists. Proximate composition of fresh minced meat and the fish cutlet viz., moisture, fat, protein and ash were analyzed by following the method described in AOAC (2000). Total Volatile Base Nitrogen (TVBN) was estimated by the micro diffusion method (Conway, 1962) while Thiobarbituricacid value was quantified using the method of Tarladgis et al., (1960).Peroxide Value (PV) and Free Fatty Acid (FFA) were determined following the method developed by Jacobs (1958) and Olley and Lovern (1960) respectively. The microbiological enumeration was carried out duly following the procedures mentioned in APHA (1992). However, spread plate technique was used to find out the microbial count for various species like Staphylococcus aureus, Escherichia coli, Faecal Streptococci, Vibrio spp., Salmonella spp., Psychrophilic bacteria and Moulds.

Experienced panel members of the institute were indulged in evaluating sensory characteristics of the fish cutlet based on a nine-point scale assigned as 9, 8, 7, 6, 5, 4, 3, 2, 1 for extremely, like very much, like moderately, like slightly, neither like nor dislike, dislike slightly, dislike moderately, dislike very much and dislike extremely respectively for each of the sensory characteristics of the product(Reddy, 1992). The characteristics covered under the taste panel were appearance, colour, odour, flavor, taste, texture and overall acceptability for fish fingers.

The Statistical Package for Social Sciences, 19 (SPSS, 2010) statistical package was used for analysis of the experimental results. Sufficient numbers of samples were carried out for each analysis. The results were expressed as mean \pm standard deviation (SD). The correlation coefficients between the parameters were carried out using the same software.

\section{Results and Discussion}

\section{Proximate composition}

The percentages of proximate composition like moisture, protein, fat, ash content of fresh rohu (Labeo rohita) mince was $78.55 \pm$ $0.24 \%, 18.78 \pm 0.02 \%, 3.29 \pm 0.01 \%$ and 1.23 \pm 0.14 respectively. The proximate composition of rohu is comparable to the other fresh water fishes (Arekere, 1993; Siddaiah et al., 2001; Panchavarnam et al., 2003; Vanitha, 2011 and Reddy et al., 2012). The estimated biochemical values like $\mathrm{pH}$, Total volatile base nitrogen (TVBN), Thiobarbutric acid (TBA) content, Peroxide value (PV), Free fatty acid (FFA) and Total plate count (TPC) of fresh minced meat were $6.51,0.98 \mathrm{mg} / 100 \mathrm{~g}$ of meat, $0.40 \mathrm{mg}$ of $\mathrm{MA} / 100 \mathrm{~g}$ of sample, $5.8 \mathrm{meqO}_{2} / \mathrm{kg}$ of fat, $0.0008 \%$, and $6.36 \times 10^{2} \mathrm{cfu} / \mathrm{g}$ of meat respectively. The lower $\mathrm{pH}$ value observed in the present study indicates the freshness of fish meat used for further processing. The TVBN, TBA, PV, FFA and TPC levels in fresh Rohu meat used in the study were below the threshold values. 
The yield of minced meat from whole fish was $39.31 \%$.However, the yield of raw mince from fresh water fishes like common carp, silver carp and catla varies from $40-47 \%$ (Arekere, 1993; Siddaiah et al., 2001; Vanitha, 2011). Quality of the final product depends mainly on the raw material characteristics and treatments, if any, given during processing (Dhanapal, 1992). The best recipe identified for the preparation of fish cutlet with various ingredients are Fish mince (45.0\%), Shrimp meat (15\%), Potatoes (10\%), Wheat flour (3.3\%), Salt (1.5\%), Mono Sodium Glutamate $(0.2 \%)$, Onion $(5 \%)$, Baking Powder $(0.1 \%)$, Egg White $(8 \%)$, Bread Crumbs (9\%), Chilli Powder (1\%), Ginger $(0.2 \%)$, Garam Masala $(1.5 \%)$ and Coriander Leaves $(0.2 \%)$. Raju et al., (2000) developed fish cutlets from crab meat while Ninan et al., (2010) developed fish cutlets from tilapia. The sensory scores obtained for various attributes like Appearance, Colour, Flavour, Odour, Taste, Texture and Overall acceptability for the selected recipe were $8.66 \pm 0.61,8.73 \pm 0.08,8.54 \pm 0.38,8.33 \pm 0.24$, $8.40 \pm 0.44, \quad 8.21 \pm 0.22$ and $8.50 \pm 0.14$ respectively.

The moisture and protein content of fish cutlet during refrigerated storage was decreased significantly from $57.03 \%$ to $52.13 \%$ and $21.74 \%$ to $18.86 \%(\mathrm{P}<0.01)$ respectively while fat and ash content were increased significantly from $7.61 \%$ to $16.76 \%$ and 3.41 $\%$ to $4.49 \%(\mathrm{P}<0.01)$ respectively (Table 1$)$. The decrease in moisture content during the refrigerated storage of cutlet was significant (P < 0.01). Reddy et al., (2012) reported a decrease in moisture content in fish cutlet prepared from reef cod mince. He concluded that the decrease in moisture content may be due to the addition of rice powder and starch to the fish paste. The reduction in protein content can be attributed to the leaching out of the water soluble nitrogenous components, during storage along with moisture. Sehgal et al., (2010) suggested that cooking can be a possible reason for reduction in the protein content. Similar observations were made by Uchak et al., (2011) and Vanitha (2011) in fish burger and fish cutlet respectively.

The increase in fat could be attributed to the decrease in moisture content as they are inversely proportional. Increase in fat content may also be attributed to cooking in oil (Sehgal et al., 2008; Tokur et al., 2006). The ash content in the product $(3.41 \%)$ was higher than the fresh fish mince $(1.23 \%)$, due to the addition of the ingredients during the preparation of fish cutlet. Vanitha (2011) also concluded that the ash content in fish cutlet and fish finger prepared from catla increased during the refrigerated storage. Similar result was observed by Reddy et al., (2012) during the storage study of cutlet prepared from reef cod mince. He reported that the higher values obtained for ash contents in the paste and cutlet blend before frying and after frying was due to the addition of salt.

In the present study, it was observed that in fish cutlet, the moisture, crude protein, lipid and ash content put together was $92 \%$ and the remaining percentage might be contributed by carbohydrates (Tokur et al., 2006). The higher percentage of carbohydrate content present in the products might be due to addition of coating materials like bread crumbs (Sayar, 2001).

\section{Biochemical changes}

The biochemical values of fish cutlet are given in Table 2. The $\mathrm{pH}$ of fish cutlet increased significantly $(\mathrm{P}<0.01)$ from6.41 to 6.78. It might be due to release of $\mathrm{CO}_{2}$ by the microbial flora present in the product (Turhan et al., 2001). Similar observation was also made by the Kilinc (2007) during the refrigeration storage of fish patties produced from anchovy. 
Table.1 Changes in the proximate composition of fish cutlet during refrigerated storage

\begin{tabular}{|c|c|c|c|c|}
\hline $\begin{array}{c}\text { Storage duration } \\
\text { (Days) }\end{array}$ & $\begin{array}{c}\text { Moisture* } \\
(\boldsymbol{\%})\end{array}$ & Crude Protein (\%) & Crude Fat (\%) & Ash (\%) \\
\hline 0 & $57.03 \pm 0.69^{\mathrm{d}}$ & $21.74 \pm 0.04^{\mathrm{i}}$ & $7.61 \pm 0.94^{\mathrm{a}}$ & $3.41 \pm 0.01^{\mathrm{a}}$ \\
\hline 1 & $55.93 \pm 0.24^{\mathrm{dc}}$ & $21.43 \pm 0.02^{\mathrm{h}}$ & $8.46 \pm 0.09^{\mathrm{a}}$ & $3.60 \pm 0.00^{\mathrm{a}}$ \\
\hline 3 & $55.23 \pm 0.12^{\mathrm{bc}}$ & $20.89 \pm 0.08 \mathrm{~g}$ & $11.73 \pm 0.52^{\mathrm{b}}$ & $3.63 \pm 0.12^{\mathrm{ab}}$ \\
\hline 5 & $54.96 \pm 0.78^{\mathrm{bc}}$ & $20.71 \pm 0.04^{\mathrm{f}}$ & $14.60 \pm 0.32^{\mathrm{c}}$ & $3.93 \pm 0.16^{\mathrm{cc}}$ \\
\hline 7 & $54.60 \pm 0.78^{\mathrm{bc}}$ & $20.33 \pm 0.09^{\mathrm{e}}$ & $15.40 \pm 0.99^{\mathrm{cd}}$ & $3.93 \pm 0.04^{\mathrm{bc}}$ \\
\hline 9 & $54.53 \pm 1.04^{\mathrm{bc}}$ & $19.9 \pm 0.08^{\mathrm{d}}$ & $15.60 \pm 0.63^{\mathrm{cd}}$ & $3.96 \pm 0.12^{\mathrm{c}}$ \\
\hline 11 & $54.10 \pm 1.55^{\mathrm{b}}$ & $19.66 \pm 0.09^{\mathrm{c}}$ & $16.03 \pm 0.04^{\mathrm{cd}}$ & $3.96 \pm 0.16^{\mathrm{c}}$ \\
\hline 13 & $53.96 \pm 0.28^{\mathrm{b}}$ & $19.33 \pm 0.06^{\mathrm{b}}$ & $16.10 \pm 0.64^{\mathrm{d}}$ & $4.10 \pm 0.16^{\mathrm{c}}$ \\
\hline 15 & $52.13 \pm 0.09^{\mathrm{a}}$ & $18.86 \pm 0.09^{\mathrm{a}}$ & $16.76 \pm 0.81^{\mathrm{e}}$ & $4.49 \pm 0.22^{\mathrm{d}}$ \\
\hline
\end{tabular}

*Each value is represented as the mean $\pm \mathrm{SD}$ of $\mathrm{n}=3$.

${ }^{\text {abcdefgh }}$ Means followed by the same superscript with in a column are not significantly different $(P>0.01)$.

Table.2 Bio-chemical changes during refrigerated storage of fish cutlet

\begin{tabular}{|c|c|c|c|c|c|}
\hline $\begin{array}{c}\text { Storage } \\
\text { duration (Days) }\end{array}$ & $\mathbf{p H}$ & $\begin{array}{c}\mathbf{P V}^{*}\left(\mathbf{m e q} \mathbf{O}_{2} / \mathbf{k g}\right. \\
\text { of fat) }\end{array}$ & $\begin{array}{c}\text { FFA* (\% of } \\
\text { oleic acid) }\end{array}$ & $\begin{array}{c}\text { TBA* (mg MA / } \\
\text { kg of sample) }^{\mathrm{a}}\end{array}$ & $\begin{array}{c}\text { TVBN* (mg /100g } \\
\text { of sample) }\end{array}$ \\
\hline 0 & $6.41 \pm 0.19^{\mathrm{a}}$ & $8.86 \pm 0.52^{\mathrm{a}}$ & $0.0022 \pm 0.00^{\mathrm{a}}$ & $0.129 \pm 0.01^{\mathrm{a}}$ & $2.80 \pm 0.00^{\mathrm{a}}$ \\
\hline 1 & $6.44 \pm 0.09^{\mathrm{b}}$ & $10.9 \pm 0.82^{\mathrm{b}}$ & $0.0028 \pm 0.00^{\mathrm{a}}$ & $0.182 \pm 0.00^{\mathrm{a}}$ & $2.83 \pm 0.04^{\mathrm{a}}$ \\
\hline 3 & $6.48 \pm 0.13^{\mathrm{b}}$ & $16.9 \pm 0.82^{\mathrm{d}}$ & $0.0029 \pm 0.00^{\mathrm{a}}$ & $0.189 \pm 0.01^{\mathrm{a}}$ & $2.87 \pm 0.05^{\mathrm{a}}$ \\
\hline 5 & $6.50 \pm 0.03^{\mathrm{b}}$ & $21.0 \pm 0.57^{\mathrm{f}}$ & $0.0030 \pm 0.00^{\mathrm{a}}$ & $0.350 \pm 0.04^{\mathrm{b}}$ & $2.93 \pm 0.04^{\mathrm{a}}$ \\
\hline 7 & $6.56 \pm 0.08^{\mathrm{b}}$ & $19.0 \pm 0.81^{\mathrm{e}}$ & $0.0045 \pm 0.00^{\mathrm{b}}$ & $0.430 \pm 0.00^{\mathrm{bc}}$ & $3.18 \pm 0.01^{\mathrm{ab}}$ \\
\hline 9 & $6.60 \pm 0.01^{\mathrm{b}}$ & $18.4 \pm 0.16^{\mathrm{e}}$ & $0.0046 \pm 0.00^{\mathrm{b}}$ & $0.440 \pm 0.00^{\mathrm{c}}$ & $3.34 \pm 0.17^{\mathrm{bc}}$ \\
\hline 11 & $6.68 \pm 0.00^{\mathrm{b}}$ & $16.8 \pm 0.14^{\mathrm{d}}$ & $0.0053 \pm 0.00^{\mathrm{bc}}$ & $0.590 \pm 0.01^{\mathrm{d}}$ & $3.41 \pm 0.17^{\mathrm{bc}}$ \\
\hline 13 & $6.73 \pm 0.00^{\mathrm{b}}$ & $13.4 \pm 0.09^{\mathrm{c}}$ & $0.0054 \pm 0.00^{\mathrm{bc}}$ & $0.740 \pm 0.01^{\mathrm{e}}$ & $3.65 \pm 0.31^{\mathrm{c}}$ \\
\hline 15 & $6.78 \pm 0.00^{\mathrm{b}}$ & $11.6 \pm 0.16^{\mathrm{b}}$ & $0.0061 \pm 0.00^{\mathrm{c}}$ & $0.860 \pm 0.08^{\mathrm{f}}$ & $4.61 \pm 0.34^{\mathrm{d}}$ \\
\hline
\end{tabular}

*Each value is represented as the mean \pm SD of $n=3$.

${ }^{\text {abcde }}$ Means followed by the same superscript with in a column are not significantly different $(\mathrm{P}>0.01)$.

Table.3 Changes in the microbial quantity in fish cutlet during refrigerated storage

\begin{tabular}{|c|c|c|}
\hline Storage period (Days) & Total plate count* (cfu/gram of meat) & Psychrophilic count* (cfu/gram of meat) \\
\hline 0 & $4.30 \times 10^{2}(2.63)$ & $2.12 \times 10^{2}(2.32)$ \\
\hline 1 & $5.40 \times 10^{2}(2.73)$ & $5.86 \times 10^{2}(2.76)$ \\
\hline 3 & $1.07 \times 10^{3}(3.03)$ & $9.42 \times 10^{2}(2.97)$ \\
\hline 5 & $4.70 \times 10^{3}(3.67)$ & $1.22 \times 10^{3}(3.08)$ \\
\hline 7 & $7.28 \times 10^{3}(3.86)$ & $2.98 \times 10^{3}(3.47)$ \\
\hline 9 & $1.23 \times 10^{4}(4.08)$ & $6.28 \times 10^{3}(3.79)$ \\
\hline 11 & $1.78 \times 10^{4}(4.25)$ & $1.67 \times 10^{4}(4.21)$ \\
\hline 13 & $3.89 \times 10^{4}(4.58)$ & $2.32 \times 10^{4}(4.36)$ \\
\hline 15 & $7.56 \times 10^{4}(4.87)$ & $4.48 \times 10^{4}(4.65)$ \\
\hline
\end{tabular}

*Each value is represented as the mean of two estimates

Figures in the parenthesis indicate Log. Bacterial count

cfu $=$ colony forming units 
Table.4 Overall acceptability of fish cutlet during refrigerated storage

\begin{tabular}{|c|c|}
\hline Storage period (Days) & Overall acceptability scores * $^{*}$ \\
\hline 0 & $8.79 \pm 0.03^{\mathrm{i}}$ \\
\hline 1 & $8.56 \pm 0.02^{\mathrm{h}}$ \\
\hline 3 & $7.69 \pm 0.04^{\mathrm{g}}$ \\
\hline 5 & $6.98 \pm 0.01^{\mathrm{f}}$ \\
\hline 7 & $6.01 \pm 0.02^{\mathrm{e}}$ \\
\hline 9 & $5.89 \pm 0.04^{\mathrm{d}}$ \\
\hline 11 & $5.21 \pm 0.02^{\mathrm{c}}$ \\
\hline 13 & $4.99 \pm 0.04^{\mathrm{b}}$ \\
\hline 15 & $4.44 \pm 0.03^{\mathrm{a}}$ \\
\hline
\end{tabular}

*Each value is represented as mean $\pm \mathrm{SD}$ of $\mathrm{n}=7$

${ }_{\text {abcdefghi }}$ Means followed by the same superscript with in a column are not significantly different $(\mathrm{P}>0.01)$.

Fig.1 Relationship of storage period with overall acceptability of fish cutlet during refrigerated storage

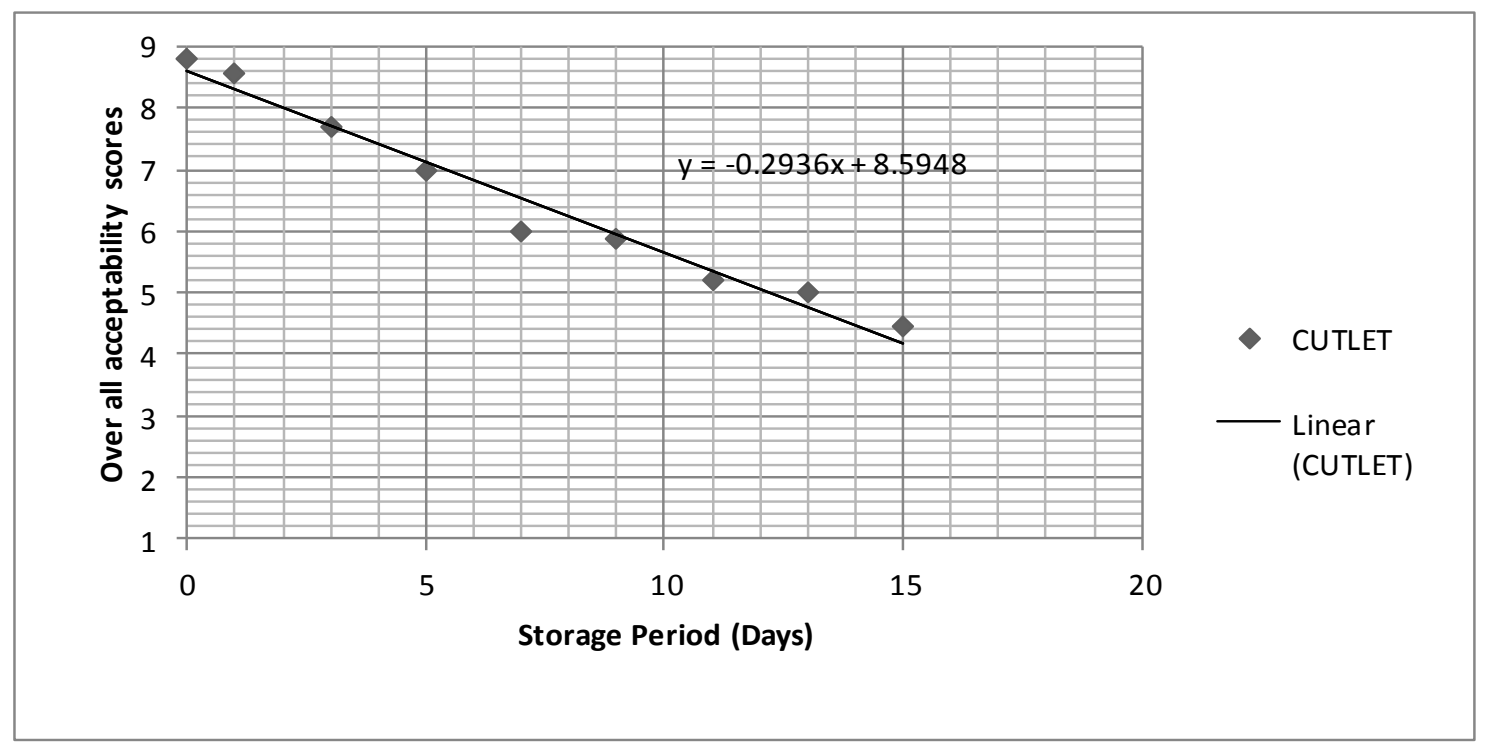

Peroxide value of fish cutlet during the initial storage period increased from 8.86 to 21.0 $\mathrm{meqO}_{2} / \mathrm{kg}$ of fat, till the end of $5^{\text {th }}$ day of storage and subsequently decreasedto11.6 $\mathrm{meqO}_{2} / \mathrm{kg}$ of fat at the end of 15 days of storage period. The fluctuation of per oxide value is due to its unstable nature and often undergoes decomposition. The decomposed products may interact with protein which would result in reduction of PV (Yerlikaya et al., 2005). Further, coating of product with egg white and spices with antioxidant properties may function as an oxygen barrier, thus preventing the fat from oxidation (Joseph et al., 1984). The free fatty acid content and TBA of fish cutlet was gradually increased from 0.0022 to $0.0061 \%$ of oleic acid and 0.129 to $0.860 \mathrm{mg} \mathrm{MA} / \mathrm{kg}$ of sample respectively $(\mathrm{P}<0.01)$. An increase in FFA was observed by the Joseph et al., (1984) and Vanitha (2011) in fish cutlets during storage at $4^{0} \mathrm{C}$ for 12 days. Increase of FFA might be 
due to enzymatic hydrolysis of esterified lipids (Hwang and Regenstein, 1993). Further the increase of FFA might be due to cooking of minced meat might have deactivated the lipolytic enzymes and consequent flash frying of the product might have led to increase of FFA (Ninan et al., 2011). TBA serves as indicator of degree of lipid oxidation (Aubourg, 1999). The development of oxidative rancidity in the product might have increased the TBA content.

As exist in the FFA and TBA, the TVBN content also steadily increased significantly $(\mathrm{P}<0.01)$ from an initial value of 2.81 to 4.61 $\mathrm{mg} / 100 \mathrm{~g}$ sample during 15 days refrigerated storage as observed by Boran and Kose (2007) and Akkus et al., (2004) in the refrigerated storage of fish balls.

Total volatile base nitrogen is known as a product of bacterial spoilage and endogenous enzymes action and its content is often used as an index to assess the keeping quality and shelf life of products (EEC, 1995). Increase of TVBN content during storage period might be due to bacterial spoilage, activity of endogenous enzymes and degradation of tissue proteins (Chomnawang et al., 2007) or production of ammonia (Adebona, 1978).

\section{Microbiological changes}

The changes in the total plate count and psychrophilic bacteria count in the fish cutlet during storage were enumerated and the results are presented in Table 3. TPC of bacteria was steadily increased $(\mathrm{P}<0.01)$ from the initial count of $4.30 \times$ to $7.56 \times 10^{4} \mathrm{cfu} / \mathrm{g}$ of sample. Similarly the psychrophilic count was also increased from $2.12 \times 10^{2}$ to $4.48 \times 10^{4} \mathrm{cfu} / \mathrm{g}$ of sample. The same increase of bacterial count was observed by Joseph et al., (1984) in fish cutlets during storage at $4^{0} \mathrm{C}$.It may be attributed to the fluctuation in the storage temperature due to power failure. However, TPC and Psychrophilic bacteria level did not exceed the maximum level of 7 Log. cfu/g of meat as described by the ICMSF (1978). Pathogenic bacteria like Salmonella spp, Vibrio spp, Staphylococcus aureus, Faecal streptococci, Escherichia coli, yeast and molds were not detected in fish cutlet during the entire period of refrigerated temperature. Absence of other pathogenic bacteria like Salmonella spp, Vibrio spp, Staphylococcus aureus, Faecal streptococci, Escherichia coli, yeast and mold might be due to flash frying of the product.

\section{Organoleptic evaluation}

The mean scores for the overall acceptability of the fish cutlet obtained during organoleptic evaluation of the product are given in Table 4. It could be observed that the overall mean acceptability scores reduced significantly $(\mathrm{P}<0.01)$ with increase of storage period (Fig. 1). The ideal shelf life for storing the fish cutlet in refrigerated condition was found as 12 days. Many researchers observed that shelf life various fish products stored in refrigerated condition are 9 to 11 days (Boranand Kose, 2007; Tasakaya et al., 2003).

With the increase in population and increase in urbanization, people are having less time and are looking for ready to eat food products. So there is a great demand for ready-to-eat fish products. From the results, it was observed that the quality of fish cutlet during refrigerated storage was within acceptable limit. Despite a decline in various sensory qualities with the increase in storage period, the fish cutlets were acceptable up to 12 days. It was established that all quality criteria mentioned above including the microbiological analysis were not reached to the maximum limits for the acceptability of fish cutlets. The current study will give an idea on the stability of cutlet and will be useful for retailers. 


\section{Acknowledgment}

The authors would like to thank the Vice Chancellor of Sri Venkateswara Veterinary University (SVVU), Tirupati, Dean of Fishery Science, SVVU, Tirupati and Associate Dean, College of Fishery science, SVVU, Muthukur for providing facility and support.

\section{References}

Adebona, M.B., (1978). Changes in total volatile bases during salt preservation of Sardinellaeda and Clupeaharengus. IPFC proceedings, monila, Philippines, (8-11 March 1978), pp. 370-374.

Akkus, O., Varlik, C., Erkan, N and Mol, S. (2004). Determination of some quality parameters of fishballs prepared from raw and boiled fish. Turkish Journal of Veterinary Animal Sciences, 28:79-85.

AOAC. (2000) Official Methods of Analysis of Association of Analytical Chemists INTERNATIONAL, $17^{\text {th }}$ Edition, Suite 500, 481 North Frederick Avenue, Gaithersburg, Maryland 20877-2417 USA.

APHA. (1992). Compendium of Methods for the Microbiological Examination of Foods, (Ed.) M. L. Speck, APHA Publication, Washington, USA.

Arekere, G. (1993). Effect of freezing and frozen storage on the properties of proteins from common carp (Cyprinus carpio) M.F.Sc thesis. University of Agricultural Sciences, Bangalore, India.

Aubourg, S.P. (1999). Lipid damage detection during the frozen storage of an underutilized fish species. Food Research International, 32:497-502.

Baygar, T., Erkan, N., Mol, S., Ozden, O., Ucok, D and Yildirim, Y. (2008) Determination of the shelf-life of trout (Oncorhynchus mykiss) raw meat ball that packed under modified atmosphere. Pakistan Journal of Nutrition, 7(3):412-
417.

Biswas, A.K., Keshri, R.C and Bisht, G.S. (2004) Effect of enrobing and antioxidants on quality characteristics of precooked pork patties under chilled and frozen storage conditions. Meat Science, 66(3):733-741.

Boran, M and Kose, M. (2007) Storage properties of three types of fried whiting balls at refrigerated temperatures. Turkish Journal of Fisheries and Aquatic Sciences, 7:65-70.

Chomnawang, C., Nantachai, K., Yongsawatd igul, J., Thawornchinsombut, $S$ and Tun gkawachara, S. (2007) Chemical and biochemical changes of hybrid catfish fillet stored at $4^{0} \mathrm{C}$ and its gel properties. Food Chemistry, 103:420-427.

Conway, E. J. 1962.Microdiffusion Analysis of Volumetric Error, $5^{\text {th }}$ ed. Crospy Lockwood and Son Ltd., London.

Dhanapal, K. 1992. Processing of chank (Xancus pyrum) meat by different methods. M.F.Sc thesis. Tamil Nadu Veterinary and Animal Sciences University, Tamil nadu, India. Pp. 62.

EEC. 1995. Decision 95/149/EC. Total volatile basic nitrogen TVBN limit values for certain categories of fishery products and specifying the analysis method to be used. Official Journal, 97: 84-87.

Elyasi, A., Zakipour Rahim Abadi, E., Sahari, M.A and Zare, P. 2010. Chemical and microbial changes of fish fingers made from mince and surimi of common carp (Cyprinus carpio L., 1758). International Food Research Journal, 17:915-920.

Gopakumar, K. 1997. Tropical fishery products. Science Publication Inc., Enfield, USA. pp: 190.

Hwang, K.T and Regenstein, J.M. 1993. Characteristics of mackerel mince lipid hydrolysis. Journal of FoodScience, 58:79-83. 
International Commission in Microbial Specification for Foods (ICMSF). 1978. Sampling plans for fish and fishery products. In: Micro-organisms in Foods, Sampling for Microbiological Analysis, Principles and Specific Applications Vol 2 (International Commission on Micro-biological Specification for Foods, ed.) pp. 92104, Toronta, Canada.

Jacobs, M.B. 1958. The chemical analysis of Foods and food products. Krieger Publication Co., New York, UK. Pp. 393-394.

Joseph, J., Perigreen, P.A and Thampuran, N. 1984. Preparation and storage of cutlet from low priced fish. Journal of Fish Technology, 21: 70-74.

Kilinc, B. 2007. Microbiological, sensory and color changes of anchovy (Engraulis encrasicholus) patties during refrigerated storage. Journal of Muscle Foods, 20:129-137.

Ninan, G., Zynudheen, A.A., Regina, $\mathrm{M}$ and Joseph, A. C. 2011. Effectiveness of spices on the quality and storage stability of freeze dried fish balls. Fishery Technology, 48(2):133-140.

Olley, J. and Lovern, J.A. 1960. Phospholipids hydrolysis of cod flesh stored at various temperatures. Journal of Science and Food Agriculture, 11:644-652.

Panchavarnam. S., Basu. S., Manisha. K., Warrier S.B. and Venugopal, V. 2003. Preparation and use of freshwater fish, rohu (Labeo rohita) protein dispersion in shelf-life extension of the fish steaks. Lebensm.-Wiss. U.-Technology. 36:433-439

Reddy, G.V.S. 1992.Development of ready to serve fish products using lactic fermentation, 44. Ph.D. Thesis, University of Agricultural Science, Bangalore.

Reddy, M. A., Elavarasan, A., Reddy, D. A., and Bhandary, M. H. 2012. Suitability of reef cod (Epinephelus diacanthus) minced meat for preparation of ready to serve product. Advances in Applied and Scientific Research, 3(3):1513-1517.

Sayar, S. 2001. A study on production of croquet from whiting fillets (Merlangiusmer langiuseuxinus L., 1758). Under graduate thesis. Ege University, Faculty of Fisheries, Izmir, Turkey. P: 25.

Sehgal, H.S and Sehgal, G. K. 2002.Aquacultural and socio-economic aspects of processing carps into some value-added products. Bioresource Technology, 82:291-293.

Sehgal, H.S., Sehgal, G.K., Thind, S.S., Kaur, A and Rehal, J. 2010. Development of "fish mince pakora" from a cultured carp species, Labeo rohita (Ham.) Journal of Food Processing and Preservation, 34:15-23

Sehgal, H.S., Shahi, M., Sehgal, G.K and Thind, S.S. 2008. Some quality aspects of fish patties prepared from an Indian major carps, Labeo rohita (Ham). Journal of Food Science Nutrition, 59:192-201.

Shankar, T.V and Ramachandran, A. 2005. Thermal stability of myofibrillar protein from Indian major carps. Journal of the Science of Food and Agriculture, 85:563-568.

Sharma, J., Reddy, G.V.S and Srikar, L.N. 2000. Effect of frozen storage on lipids and functional properties of proteins of dressed Indian oil sardine (Sardinalla longiceps). Food Research International, 33:815-820.

Siddaiah, D., Reddy, G.V.S., Raju, C.V and Chandrasekhar, T.C. 2001. Changes in lipids, proteins and kamaboko forming ability of silver carp (Hypophthalmich thysmolitrix) mince during frozen storage. Food Research International, 34:47-53. 
SPSS., 2000, SPSS for windows. Release 10. Chicago, 11:SPSS Inc.

Tarladgis, B.G., Watts, M. and Younathan, M. 1960.A distillation method for the quantitative determination of malonaldehyde in rancid foods. Journal of Oil Chemistry Society, 37:44-48.

Tokur, B., Ozkutuk, S., Atici, E., Ozyurt, G and Ozyurt, C.E. 2006. Chemical and sensory quality changes of fish fingers, made from mirror carp (Cyprinus carpio), during frozen storage $\left(-18^{\circ} \mathrm{C}\right)$. Food Chemistry, 99:335-341.

Tokur, B., Polat, A., Beklevik, $\mathrm{G}$ and Ozkutuk, S. 2004. The quality changes of tilapia (Oreochromis niloticus) burger during frozen storage. European Food Research and Technology, 218(5):420-423.

Vanitha, M. 2011. Development of value added products from catla (Catla catla) and its quality evaluation. M.F.Sc, Thesis, Sri Venkateswara Veterinary University, Tirupati.

Yerlikaya, P., Gokoglu, N and Uran, H. 2005. Quality changes of fish patties produced from anchovy during refrigerated storage. European Food Research Technology, 220:287-291.

\section{How to cite this article:}

Sowmya Praneetha, S., K. Dhanapal, G.V.S. Reddy, A. Balasubramanian and Praveen Kumar, G. 2017. Studies on the Quality of Fish Cutlet Prepared from Rohu (Labeo rohita) during Refrigerated Storage. Int.J.Curr.Microbiol.App.Sci. 6(12): 3262-3271.

doi: https://doi.org/10.20546/ijcmas.2017.612.379 